\title{
DAMPAK INVESTASI PEMERINTAH DAN INVESTASI SWASTA TERHADAP PERTUMBUHAN EKONOMI DAN KESEJAHTERAAN MASYARAKAT DI PROVINSI MALUKU
}

\author{
Tri Wahyuningsih \\ Fakultas Ekonomi Universitas Iqra Buru (UNIQBU) Maluku \\ E-mail: riz_180506@yahoo.com \\ HP. 081343232954
}

\begin{abstract}
The objective of the study is to test and analyze: first, the influence of public investment toward economic growth; second, the influence of public investment toward society welfare; third, the influence of private investment toward economic growth; fourth, the influence of private invsetment toward society welfare; fifth, the influence of economic growth toward society welfare in Maluku Province. The Analysis method used is this study is path analysis by using SPSS program package. The secondary data used are panel data, which is the combination of data from 2005 until 2008 and cross data including 7 districts and 1 municipality in Maluku Province. The study generates conclusions that: first, public investment has a significant influences toward economic growth and has positive relationship direction. Second, public investment has a significant influences toward society welfare. Third, private investment has a significant influences toward economic growth and has positive relationship direction. Fourth, private investment has a significant influence toward society welfare and has positive relationship direction. Fifth, economic growth significantly influences society welfare and has positive relationship direction. Than, the dominant variable which effect society welfare is public investment, while the smallest contibution effect toward welfare growth is private investment.
\end{abstract}

Keywords: government investment, private investment, economic growth, society welfare.

Lahirnya Undang-Undang Nomor 22 Tahun 1999 telah membuka peluang bagi daerah untuk memekarkan diri, menjadi daerah baru, kabupaten, kota ataupun menjadi provinsi baru. Salah satu provinsi di Indonesia yang mengalami pemekaran darah provinsi dan kabupten kota setelah otonomi daerah adalah provinsi Maluku. Pemekaran wilayah dianggap sebagai solusi alternatif supaya pembangunan dapat lebih merata di seluruh wilayah di Indonesia. Semakin dekat pemerintah dengan daerahnya, maka diyakini semakin baik juga penyediaan 
barang publik dapat dilakukan. Hal ini disebabkan oleh karena pemerintah daerah benar-benar mengetahui secara pasti karakteristik barang publik yang paling tepat sesuai dengan keadaan daerah masing-masing.

Salah satu tujuan pemekaran daerah adalah untuk meningkatkan pelayanan publik guna mempercepat terwujudnya kesejahteraan masyarakat. Hal penting utama yang perlu dikaji adalah sejauh mana "input" yang diperoleh pemerintah daerah pemekaran dapat digunakan semaksimal mungkin untuk meningkatkan kesejahteraan masyarakat (BAPPENAS dan UNDP.2008:5). Berlakunya undangundang otonomi daerah telah memberikan peluang bagi daerah untuk menggali potensi lokal dan tingkat independensi pemerintah daerah di bidang keuangan semakin meningkat. Artinya pemerintah daerah memiliki keleluasaan dalam merencanakan dan menentukan arah pembangunan, menggali sumber-sumber penerimaan, menentukan prioritas serta kegiatannya. Litvack and Seddon dalam Prawirosetoto (2002) menyatakan bahwa desentralisasi fiskal adalah pendelegasian tanggung jawab dan pembagian kekuasaan dan kewenangan untuk pengambilan keputusan di bidang fiskal yang meliputi aspek penerimaan (tax assignment) maupun aspek pengeluaran (expenditure assignment) sehingga pemerintah daerah akan memperoleh transfer dari pusat dalam rangka keseimbangan fiskal. Dengan demikian maka pemerintah daerah yang telah diberi keleluasaan untuk mengatur pengeluarannya tersebut sudah sewajarnya apabila Anggaran Pendapatan dan Belanja Daerah dialokasikan untuk kepentingan publik dalam bentuk investasi pemerintah. Oleh karenanya salah satu aspek yang perlu menjadi perhatian adalah pemanfaatan semaksimal mungkin keuangan daerah bagi pelayanan publik serta mendorong perekonomian daerah melalui belanja modal.

Investasi pemerintah daerah dalam Anggaran Pendapatan dan Belanja Daerah (APBD) tercermin melalui belanja modal yang dianggarkan setiap tahunnya. Adanya peningkatan penerimaan APBD kabupaten kota di provinsi Maluku disetiap tahun ternyata tidak dikuti dengan peningkatan dana yang dialokasikan untuk investasi. Hal ini tentunya akan berdampak terhadap penyediaan sarana fisik dan prasarana yang memadai bagi daerah kabupaten dan kota yang mengalami pemekaran. Keterbatasan infrastruktur secara langsung akan 
menyebabkan potensi ekonomi provinsi Maluku tak kunjung dapat didayagunakan secara optimal.

Suatu iklim investasi (infrastruktur) yang baik maka akan semakin menarik daerah tersebut untuk dijadikan investasi bagi perusahaan-perusahaan swasta, dari para petani dan wirausahawan mikro sampai dengan perusahaan manufaktur lokal dan perusahaan multinasional. Perusahaan-perusahaan tersebut melakukan investasi pada gagasan-gagasan serta fasilitas-fasilitas baru yang memperkuat fondasi pertumbuhan dan kesejahteraan ekonomi (The World Bank.2004:2). Nilai investasi swasta dalam negeri maupun asing di provinsi Maluku pada umumnya tidak menunjukkan adanya kecenderungan nilai investasi yang meningkat setiap tahunnya, tetapi berfluktuasi. Padahal, salah satu cara untuk merangsang pertumbuhan ekonomi adalah investasi, baik investasi dari luar negeri maupun investasi dalam negeri. Investasi swasta merupakan salah satu aspek yang perlu diberdayakan di daerah, karena salah satu inti dari otonomi daerah dan pemekaran wilayah adalah pemberdayaan daerah dimana merupakan suatu proses pembelajaran dan penguatan bagi daerah untuk mampu mengatur, mengurus dan mengelola kepentingan dan aspirasi masyarakatnya sendiri.

Dalam konteks otonomi daerah yang saat ini tengah berlangsung, idealnya investasi swasta adalah sebagai salah satu pendorong pembangunan di Provinsi Maluku. Sudah saatnya Provinsi Maluku berkompetisi menarik sebanyak mungkin investasi swasta sebagai penggerak pembangunan daerah sehingga potensi daerah dapat dimanfaatkan secara optimal bagi masyarakat. Kehadiran investasi swasta sangat penting dalam menunjang pembangunan daerah dan penurunannya dapat berdampak serius. Hal ini disebabkan karena kalau invesatsi turun, maka kegiatankegiatan produksipun akan ikut turun. Jika kegiatan produksi turun, dengan sendirinya output pun merosot, dan apabila penurunan ini terjadi terus-menerus maka pada gilirannya laju pertumbuhan ekonomi secara keseluruhan akan merosot.

Berdasarkan data distribusi persentase pertumbuhan ekonomi menurut lapangan usaha di Provinsi Maluku, sektor pertanian, peternakan, kehutanan, perikanan dan sektor jasa-jasa mengalami penurunan terus-menerus dari tahun 2005 sampai dengan tahun 2008. Ini menunjukkan bahwa kedua sektor tersebut 
belum dikembangkan dengan baik dan optimal sehingga kontribusinya terhadap output dari tahun ke tahun semakin kecil. Padahal Maluku memiliki potensi sumber daya alam yang cukup berlimpah.

Luas keseluruhan areal Provinsi Maluku, 90,85 \% merupakan perairan laut atau nisbah antara laut dan daratan adalah 9:1, sehingga sangat berpeluang untuk pengembangan usaha perikanan tangkap, pengembangan potensi budidaya laut dan pengembangan industri pengolahan ikan (Tim Peneliti Soegeng Sarjadi Syndicated. 2001:1005). Kenyataan ini menunjukkan bahwa mau tidak mau masyarakat provinsi Maluku harus meningkatkan pendayagunaan dan pemanfaatan sumber daya alam yang terkandung di dalamnya sehingga keunggulan utama wilayah laut Maluku terletak pada besarnya peluang pemanfaatan dan pengembangan keanekaragaman hayati (perikanan) yang dikandungnya. Dengan demikian, sub sektor kelautan di Maluku juga merupakan salah satu potensi handalan sektor perikanan. Tentu semua ini tidak akan bermakna apa-apa jika tidak dikembangkan guna meningkatkan kontribusi sektor tersebut sehingga dapat meningkatkan pertumbuhan ekonomi.

Keberhasilan pembangunan tidak hanya diukur dari tingkat pertumbuhan ekonomi (PDRB), tetapi juga dengan indikator pembangunan masyarakat yang lebih baik seperti tingkat harapan hidup yang lebih lama dan jangkauan pendidikan yang lebih luas. Oleh karena itu, pembangunan manusia yang diukur dengan Indeks Pembangunan Manusia (IPM) adalah salah satu diantara indikator pembangunan yang dapat digunakan untuk mengukur keberhasilan pembangunan. IPM kabupaten kota di provinsi Maluku apabila dibandingkan dengan keseluruhan perkembangan rata-rata daerah lain di Indonesia, Indeks Pembangunan Manusia Provinsi Maluku masih rendah. Rendahnya angka IPM ini akan sangat tidak menguntungkan bagi kelangsungan pembangunan berikutnya, karena sumber daya manusia merupakan sentral keberlangsungan pembangunan. Oleh sebab itu, merupakan langkah sangat strategis jika pada era otonomi daerah dan terbentuknya daerah-daerah otonom baru di provinsi Maluku, perhatian terhadap sumber daya manusia ditangani secara lebih awal dan dilakukan secara sungguh-sungguh. 
Berdasarkan atas uraian tersebut, maka salah satu sumber penting bagi tercapainya pembangunan yang berkualitas setelah pemekaran daerah kabupaten kota di provinsi Maluku adalah adanya investasi, yakni investasi pemerintah maupun investasi swasta yang diharapkan akan meningkatkan tingkat pertumbuhan ekonomi serta kesejahteraan masyarakat. Keterkaitan atas hal-hal yang telah diuraikan itu, maka cukup menarik dan penting untuk melihat dampak investasi pemerintah dan investasi swasta terhadap pertumbuhan ekonomi serta kesejahteraan masyarakat di provinsi Maluku.

Berdasarkan latar belakang diatas, maka rumusan masalahnya adalah pertama, apakah investasi pemerintah berpengaruh terhadap pertumbuhan ekonomi?, kedua apakah investasi pemerintah berpengaruh terhadap kesejahteraan masyarakat?, ketiga apakah investasi swasta berpengaruh terhadap pertumbuhan ekonomi?, keempat apakah investasi swasta berpengaruh terhadap kesejahteraan masyarakat? dan kelima apakah pertumbuhan ekonomi berpengaruh terhadap kesejahteraan masyarakat?

Adapun kerangka konseptual dari penelitian ini adalah sebagai berikut:

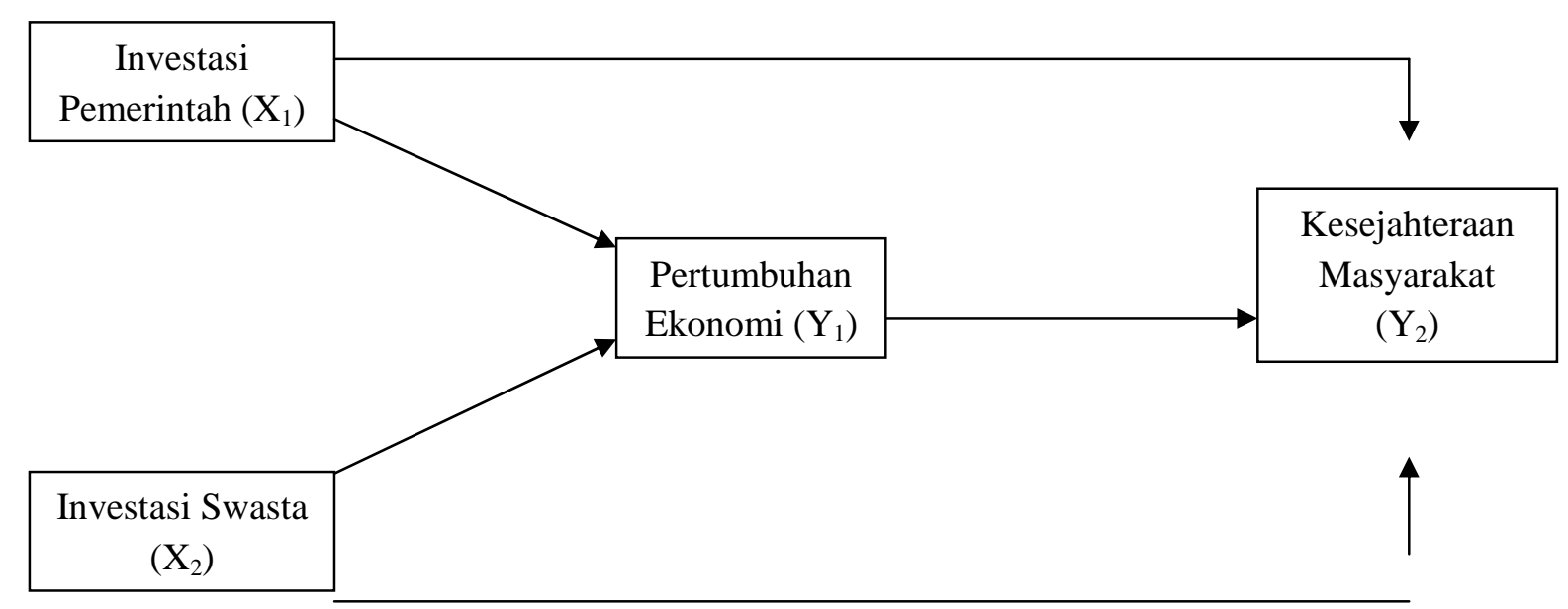

Gambar 1. Kerangka Konseptual

Berdasarkan hubungan pengaruh antara variabel yang berlandaskan studi teoritik dan studi empirik maka disusun kerangka konseptual penelitian yang nampak pada Gambar 1. Gambar tersebut menunjukkan bahwa kerangka konseptual penelitian ini adalah untuk menguji dan menganalisis baik secara 
langsung maupun tidak langsung pengaruh investasi pemerintah dan investasi swasta terhadap pertumbuhan ekonomi serta kesejahteraan masyarakat. Analisis terhadap hubungan antar variabel tersebut menggunakan Path Analysis, dimana pendekatannya dapat melihat pengaruh suatu variabel terhadap variabel yang lain baik pengaruh langsung (direct effect) maupun pengaruh tidak langsung (indirect effect).

\section{Hipotesis}

1. Investasi pemerintah berpengaruh signifikan terhadap pertumbuhan ekonomi.

2. Investasi pemerintah berpengaruh signifikan terhadap kesejahteraan masyarakat.

3. Investasi swasta berpengaruh signifikan terhadap pertumbuhan ekonomi.

4. Investasi swasta berpengaruh signifikan terhadap kesejahteraan masyarakat.

5. Pertumbuhan ekonomi berpengaruh signifikan terhadap kesejahteraan masyarakat.

\section{METODE}

Unit analisis penelitian ini adalah Kabupaten/Kota yang berada di Provinsi Maluku, oleh sebab itu seluruh Kabupaten/Kota yang berada di Provinsi Maluku disebut sebagai populasi. Populasi dalam penelitian ini meliputi seluruh Kabupaten/Kota yang berada di Provinsi Maluku yang berjumlah 8 daerah terdiri dari: Kota Ambon, Kabupaten Maluku Tenggara Barat, Kabupaten Maluku Tenggara, Kabupaten Maluku Tengah, dan Kabupaten Buru, Kabupaten Seram Bagian Barat, Kabupaten Seram Bagian Timur dan Kabupaten Kepulauan Aru.

Data pada penelitian ini berupa data sekunder yang diperoleh dari dokumentasi Badan Pusat Statistik (BPS) pusat maupun BPS provinsi Maluku. Data diambil secara runtun waktu (time series) dan data silang (cross section) yang disebut sebagai data panel atau poling data. Data runtut waktu mulai tahun 2005 sampai dengan tahun 2008, sedangkan data silang meliputi seluruh Kabupaten/Kota di Provinsi Maluku yang berjumlah 8 daerah. Penggabungkan (pooling) data dari delapan kabupaten dan kota selama 4 tahun tersebut sudah memenuhi syarat dalam menggunakan metode SPSS (Statistical Package for Sosial Science). 
Teknik analisis yang digunakan dalam penelitian ini adalah path analysis (analisis jalur atau lintasan). Tujuan path analysis adalah menerangkan akibat langsung dan tidak langsung seperangkat variabel, sebagai variabel penyebab, terhadap variabel lainnya yang merupakan variabel akibat (Muhidin.2007:221).

\section{HASIL}

Tabel 1. Hasil Pengujian Hipotesis Pada Setiap Jalur

\begin{tabular}{|c|c|c|c|}
\hline Pengaruh Antar Variabel & $\begin{array}{c}\text { Koefisien } \\
\text { Jalur }(\beta)\end{array}$ & $\begin{array}{c}\rho- \\
\text { Value }\end{array}$ & $\begin{array}{c}\text { Hasil } \\
\text { Pengujian }\end{array}$ \\
\hline $\begin{array}{c}\text { Investasi Pemerintah } \vec{\rightarrow} \\
\text { Pertumbuhan Ekonomi }\end{array}$ & 0,471 & 0,019 & Signifikan \\
\hline $\begin{array}{l}\text { Investasi Pemerintah } \vec{\rightarrow} \\
\text { Kesejahteraan Masyarakat }\end{array}$ & 0,747 & 0,000 & Signifikan \\
\hline $\begin{array}{l}\text { Investasi Swasta } \rightarrow \\
\text { Pertumbuhan Ekonomi }\end{array}$ & 0,394 & 0,045 & Signifikan \\
\hline $\begin{array}{c}\text { Investasi Swasta } \rightarrow \\
\text { Kesejahteraan Masyarakat }\end{array}$ & 0,075 & 0,004 & Signifikan \\
\hline $\begin{array}{c}\text { Pertumbuhan Ekonomi } \vec{\rightarrow} \\
\text { Kesejahteraan Masyarakat }\end{array}$ & 0,601 & 0,000 & Signifikan \\
\hline
\end{tabular}

Sumber: data diolah

Tabel 2. Koefisien Jalur Pengaruh Langsung dan Tidak Langsung

\begin{tabular}{|c|c|c|}
\hline \multirow{2}{*}{ Pengaruh Variabel } & \multicolumn{2}{|c|}{ Pengaruh Kausal } \\
\cline { 2 - 2 } & Langsung & Tidak Langsung Melalui \\
\cline { 2 - 2 } & 0,471 & \\
\hline $\begin{array}{c}\text { Investasi Pemerintah } \rightarrow \\
\text { Pertumbuhan Ekonomi }\end{array}$ & & \multirow{2}{*}{$(0,471) \times(0,601)=\mathbf{0 , 2 8 3 0}$} \\
\hline $\begin{array}{c}\text { Investasi Pemerintah } \rightarrow \\
\text { Kesejahteraan Masyarakat }\end{array}$ & 0,747 & \\
\hline $\begin{array}{c}\text { Investasi Swasta } \rightarrow \\
\text { Pertumbuhan Ekonomi }\end{array}$ & 0,394 & \multirow{2}{*}{$(0,394) \times(0,601)=\mathbf{0 , 2 3 6 7}$} \\
\hline $\begin{array}{c}\text { Investasi Swasta } \rightarrow \\
\text { Kesejahteraan Masyarakat }\end{array}$ & 0,075 & \\
\hline $\begin{array}{c}\text { Pertumbuhan Ekonomi } \rightarrow \\
\text { Kesejahteraan Masyarakat }\end{array}$ & 0,601 & \\
\hline
\end{tabular}

Sumber : data diolah 


\section{Pengaruh Langsung Substruktur Pertama}

Dalam persamaan substruktur pertama terdapat dua variabel eksogen yakni investasi pemerintah $\left(\mathrm{X}_{1}\right)$ dan Investasi Swasta $\left(\mathrm{X}_{2}\right)$ dengan variabel endogen Pertumbuhan Ekonomi $\left(\mathrm{Y}_{1}\right)$.

$$
Y_{1}=\rho y_{1} x_{1} \times X_{1}+\rho y_{1} x_{2} \times X_{2}+\varepsilon_{1}
$$

Besarnya pengaruh dari investasi pemerintah terhadap perubahanperubahan variabel pertumbuhan ekonomi adalah sebesar 0,471. Berdasarkan hasil perhitungan diatas dapat dikemukakan bahwa besarnya kontribusi investasi pemerintah $\left(\mathrm{X}_{1}\right)$ yang secara langsung mempengaruhi pertumbuhan ekonomi $\left(\mathrm{Y}_{1}\right)$ adalah $0,471^{2}=22,18 \%$. Maknanya, variasi dari perubahan variabel pertumbuhan ekonomi sekitar 22,18\% disebabkan karena perubahan-perubahan dari variabel investasi pemerintah. Sisanya sebesar $77,82 \%$ diakibatkan faktor-faktor lain yang tidak masuk dalam persamaan, tetapi ditampung pada variabel gangguan acak.

Sedangkan besarnya pengaruh dari investasi swasta terhadap perubahanperubahan variabel pertumbuhan ekonomi adalah sebesar 0,394. Berdasarkan hasil perhitungan diatas dapat dikemukakan bahwa besarnya kontribusi investasi pemerintah $\left(\mathrm{X}_{2}\right)$ yang secara langsung mempengaruhi pertumbuhan ekonomi $\left(\mathrm{Y}_{1}\right)$ adalah $0,394^{2}=15,52 \%$. Maknanya, variasi dari perubahan variabel pertumbuhan ekonomi sekitar 15,52\% disebabkan karena perubahan-perubahan dari variabel investasi pemerintah. Sisanya sebesar $84,48 \%$ diakibatkan faktor-faktor lain yang tidak masuk dalam persamaan, tetapi ditampung pada variabel gangguan acak e.

\section{Pengaruh Langsung dan Tidak Langsung Substruktur Kedua}

Pada persamaan ini ada tiga variabel eksogen yang terdiri atas 2 variabel langsung eksogen yakni investasi pemerintah $\left(\mathrm{X}_{1}\right)$ dan investasi swasta $\left(\mathrm{X}_{2}\right)$ serta 1 variabel intervening endogen yaitu pertumbuhan ekonomi $\left(\mathrm{Y}_{1}\right)$.

$$
Y_{2}=\rho y_{2} x_{1} x X_{1}+\rho y_{2} x_{2} x X_{2}+\rho y_{2} y_{2} x Y_{1}+\varepsilon_{2}
$$

Besarnya kontribusi investasi pemerintah $\left(\mathrm{X}_{1}\right)$ yang secara langsung mempengaruhi kesejahteraan masyarakat $\left(\mathrm{Y}_{2}\right)$ adalah $0,747^{2}=55,80 \%$. Maknanya, kesejahteraan masyarakat ditentukan oleh investasi pemerintah sebesar 
$55,80 \%$. Sisanya sebesar 44,20\% merupakan kontribusi dari varaibel lain di luar variabel investasi pemerintah yang mempengaruhi kesejahteraan masyarakat.

Sedangkan besarnya kontribusi investasi swasta $\left(\mathrm{X}_{2}\right)$ yang secara langsung mempengaruhi kesejahteraan masyarakat $\left(\mathrm{Y}_{2}\right)$ adalah $0,075^{2}=0,56 \%$. Maknanya, kesejahteraan masyarakat ditentukan oleh investasi swasta sebesar 0,56\%. Sisanya sebesar 99,43\% merupakan kontribusi dari variabel lain di luar variabel investasi swasta mempengaruhi kesejahteraan masyarakat. Sedangkan besarnya kontribusi pertumbuhan ekonomi $\left(\mathrm{Y}_{1}\right)$ yang secara langsung mempengaruhi kesejahteraan masyarakat $\left(\mathrm{Y}_{2}\right)$ adalah $0,601^{2}=36,12 \%$. Maknanya, kesejahteraan masyarakat ditentukan oleh investasi swasta sebesar 36,12\%. Sisanya sebesar $63,88 \%$ merupakan kontribusi dari varaibel lain di luar variabel pertumbuhan ekonomi yang mempengaruhi kesejahteraan masyarakat.

Hasil perkalian investasi pemerintah terhadap kesejahteraan masyarakat melalui pertumbuhan ekonomi diperoleh nilai koefisien jalur 0,2830 (28,30\%). Angka tersebut lebih kecil dibandingkan dengan nilai koefisien pengaruh langsung investasi pemerintah terhadap kesejahteraan masyarakat sebesar $0,747^{2}$ $(55,80 \%)$. Hasil perkalian investasi swasta terhadap kesejahteraan masyarakat melalui pertumbuhan ekonomi diperoleh nilai koefisien jalur 0,2367 (23,67\%). Angka tersebut lebih besar dibandingkan dengan nilai koefisien pengaruh langsung investasi swasta terhadap kesejahteraan masyarakat sebesar $0,075^{2}$ $(0,56 \%)$. Kesimpulannya, investasi pemerintah cenderung berpengaruh secara langsung terhadap kesejahteraan masyarakat, sedangkan investasi swasta cenderung mempengurhi kesejahteraan masyarakat melalui pertumbuhan ekonomi.

\section{PEMBAHASAN}

Hasil estimasi pengaruh langsung investasi pemerintah terhadap pertumbuhan ekonomi menunjukkan pengaruh positif dan signifikan dengan nilai koefisien jalur sebesar 0,470 dan nilai probabilitas sebesar 0,019 . Pengaruh positif menunjukkan hubungan yang searah antara investasi pemerintah dengan pertumbuhan ekonomi. Artinya, peningkatan investasi pemerintah akan berdampak pada peningkatan pertumbuhan ekonomi di provinsi Maluku, demikian juga sebaliknya. Dengan demikian, berdasarkan pengujian hipotesis 
yang menyatakan bahwa investasi pemerintah berpengaruh signifikan terhadap pertumbuhan ekonomi kabupaten kota di provinsi Maluku adalah terbukti dan didukung oleh fakta.

Fakta dari temuan studi ini adalah bahwa investasi pemerintah di provinsi Maluku walaupun pada tahun tertentu ada kabupaten yang nilai investasi pemerintahnya mengalami penurunan, namun secara keseluruhan investasi pemerintah yang diproxy dari belanja modal pada APBD mengalami kenaikan. Hubungan antara investasi pemerintah (belanja modal) dan PDRB ini dapat digambarkan dengan angka elastisitas yang menunjukkan seberapa jauh peranan investasi pemerintah terhadap tingkat pertumbuhan ekonomi. Laju pertumbuhan ekonomi di provinsi Maluku pada tahun 2005 hingga tahun 2008 secara berurutan adalah $5,07 \%, 5,55 \%, 5,62 \%$ dan 4,23\%. Kemudian laju pertumbuhan investasi pemerintah secara berurutan yang dimulai pada tahun 2005/2006 adalah 106,94 $\%$, 52,81 \%, dan 19,01 \%. Dari angka-angka tersebut dihasilkan elastisitas pertumbuhan ekonomi terhadap investasi pemerintah adalah 0,05 di tahun 2006, 0,106 di tahun 2007, dan 0,222 di tahun 2008. Berdasarkan angka elastisitas tersebut, investasi pemerintah yang memacu laju pertumbuhan ekonomi dari tahun 2006 hingga tahun 2008 mengalami peningkatan. Artinya, pertumbuhan ekonomi di provinsi Maluku yang ditimbulkan oleh investasi pemerintah kontribusinya semakin besar.

Fakta studi ini memperkuat teori yang dikemukakan oleh Rostow dan R.A Musgrave, yang menghubungkan pengeluaran pemerintah dengan tahap-tahap pembangunan ekonomi. Pada tahap awal perkembangan ekonomi, menurut mereka rasio investasi pemerintah terhadap pendapatan nasional relatif besar. Hal itu disebabkan oleh karena pada tahap ini pemerintah harus menyediakan berbagai prasarana seperti pendidikan, kesehatan, dan prasarana transportasi.

Pemekaran daerah di provinsi Maluku memungkinkan pemerintah memperbaiki pemerataan fasilitas pendidikan, baik di tingkat dasar maupun lanjutan. Rentang kendali yang lebih pendek dan dan alokasi fiskal yang lebih merata seyogyanya menjadi modal dasar bagi peningkatan pelayanan bidang pendidikan. Seiring dengan bertambah pula jumlah murid dari tahun 2005 sampai dengan tahun 2008, rasio murid terhadap ruang kelas yang mengalami 
peningkatan dibanding dengan jumlah murid di Provinsi Maluku adalah Sekolah Dasar (SD). Secara keseluruahan, total angka rasio adalah sebesar 30,20 di tahun 2005 dan 30,27 di tahun 2008. Angka tersebut apabila dibandingkan dengan patokan BPS bahwa angka 40 dianggap cukup baik, maka rasio murid terhadap ruang kelas di provinsi Maluku dapat dikatakan baik.

Dalam konteks ini, sarana pendidikan dianggap sebagai alat untuk mencapai target yang berkelanjutan, karena dengan pendidikan aktivitas pembangunan dapat tercapai, sehingga peluang untuk meningkatkan kualitas hidup di masa depan akan lebih baik. Di sisi lain, dengan pendidikan, usaha pembangunan yang lebih hijau (greener development) dengan memperhatikan aspek-aspek lingkungan juga mudah tercapai. Romer, 1986; Lucas, 1988 (dalam Cui et.,al. 2008) menjelaskan bahwa modal manusia tidak hanya diidentifikasi sebagai kontributor kunci dalam pertumbuhan dan pengurangan kemiskinan, namun juga mendorong tujuan pembangunan untuk meningkatkan human freedom secara umum.

Model pertumbuhan endogen (endogenous growth) meyakini bahwa investasi dalam pendidikan dapat meningkatkan modal manusia dalam perekonomian. Investasi pendidikan dianggap memiliki implikasi yang positif terhadap penambahan sumber daya bagi perekonomian, sehingga dapat meningkatkan output secara umum. Oleh karena itu, perubahan dalam pengeluaran bidang pendidikan yang dipengaruhi oleh kebijakan fiskal jangka pendek akan mendukung proses akumulasi dalam modal manusia sehingga pada akhirnya akan mendorong pertumbuhan ekonomi (Keuschnigg and Fisher, 2002 Dalam Zagler and Durnecker, 2003).

Temuan studi ini mendukung hasil penelitian sebelumnya yang dilakukan oleh Loizides John dan George Vamvoukas (2005) dengan kesimpulan bahwa pengeluaran pemerintah menyebabkan pertumbuhan ekonomi di Negara Yunani, Inggris dan Irlandia untuk jangka pendek, sedangkan untuk jangka panjang hanya terjadi di negara Inggris dan Irlandia. Temuan studi ini memiliki kesamaan dengan laporan pembangunan dunia dari Bank Dunia (The World Bank. 2004:51), perusahaan-perusahaan di negara-negara bagian India serta provinsi-provinsi di Cina dengan iklim investasi lebih baik menunjukkan pertumbuhan dan 
produktivitas yang lebih kuat daripada perusahaan-perusahaan lain di negara bagian atau provinsi dengan iklim investasi yang kurang baik. Kemudian, hasil studi ini sejalan dengan pendapat Keynes (Keynesian Causality) yang menyatakan bahwa pengeluaran pemerintah merupakan faktor eksogen yang dapat digunakan sebagai instrumen kebijakan untuk meningkatkan PDB melalui efek multiplier. Posisi variabel pengeluaran pemerintah menjadi suatu kebijakan yang dapat digunakan untuk mempengaruhi pertumbuhan ekonomi.

\section{Pengaruh Investasi Pemerintah Terhadap Kesejahteraan Masyarakat}

Hasil estimasi pengaruh langsung investasi pemerintah terhadap kesejahteraan masyarakat menunjukkan pengaruh positif dan signifikan dengan nilai koefisien jalur sebesar 0,747 dan nilai probabilitas sebesar 0,000. Pengaruh positif menunjukkan hubungan yang searah antara investasi pemerintah dengan kesejahteraan masyarakat. Artinya, peningkatan investasi pemerintah akan berdampak pada peningkatan kesejahteraan masyarakat di provinsi Maluku, demikian juga sebaliknya. Dengan demikian, berdasarkan pengujian hipotesis yang menyatakan bahwa investasi pemerintah berpengaruh signifikan terhadap kesejahteraan masyarakat kabupaten kota di provinsi Maluku adalah terbukti dan didukung oleh fakta.

Temuan studi ini tidak bertentangan dengan fakta bahwa, peningkatan Indeks Pembangunan Manusia (IPM) di provinsi Maluku, diiringi sebelumnya oleh peningkatan nilai investasi pemerintah yang diantaranya ditujukan untuk pembangunan sarana kesehatan. Upaya peningkatan aspek kesehatan sangat penting di provinsi Maluku karena untuk meningkatkan kualitas sumber daya manusia harus di mulai dari aspek ini. Peningkatan derajat kesehatan tersebut harus di mulai dengan peningkatan sarana dan fasilitas kesehatan. Untuk melihat apakah sarana kesehatan cukup memadai digunakan perbandingan jumlah sarana kesehatan terhadap sejumlah tertentu penduduk (10.000).

Sarana kesehatan pemerintah seperti Rumah Sakit, Puskesmas, Pukesmas pembantu dan juga tempat tidur di provinsi Maluku mengalami perkembangan dari tahun 2005 ke tahun 2008. Adanya perkembangan sarana kesehataan tersebut, maka rasio fasilitas kesehatan pemerintah per 10.000 penduduk pun ikut meningkat. Hal ini menunjukkan bahwa semakin banyak jumlah sarana kesehatan 
yang tersedia sehingga makin banyak penduduk yang dapat dilayani. Kondisi tersebut mengindikasikan bahwa investasi pemerintah yang salah satunya ditujukan untuk pembangunan sarana kesehatan tersebut telah berdampak terhadap tingkat kesejahteraan masyarakat kabupaten kota provinsi Maluku yang tercermin dari peningkatan indikator kesehatan dalam IPM. Angka harapan hidup di tahun 2005 telah meningkat dari 66,60 tahun menjadi 69,20 tahun di tahun 2008. Mengingat angka harapan hidup di provinsi Maluku masih lebih rendah jika dibandingkan rerata daerah lain di Indonesia, maka hal lain yang perlu menjadi perhatian pemerintah daerah adalah membaiknya sarana kesehatan tersebut sebaiknya diikuti pula dengan peningkatan kualitas dan efektifitas pelayanan itu sendiri. Hal ini dilakukan agar supaya sarana pemerintah yang ada tersebut dapat secara optimal mendorong peningkatan kesejahteraan masyarakat. Bukti adanya keterkaitan antara investasi pemerintah dalam hal perbaikan iklim investasi dengan peningkatan kesejahteraan masyarakat adalah yang dilakukan oleh World Bank (The World Bank. 2004:52). Hasil laporan pembangunan Bank Dunia menunjukkan bahwa perbaikan iklim investasi di Cina dan India telah berhasil mengangkat 400 juta orang keluar dari kemiskinan. Peningkatan dalam pendapatan juga diimbangi dengan peningkatan dalam pencapaian keadaan kesehatan. Di Cina, tingkat harapan hidup naik sebesar empat tahun dari 66,8 tahun ke 70,7 tahun selama tahun 1980 sampai dengan tahun 2002, dan tingkat mortalitas bayi turun dari 49 ke 32 per 1.000 kelahiran hidup. Di India, tingkat harapan hidup naik dari 54 tahun menjadi 63 tahun, tingkat mortalitas bayi turun sebesar $40 \%$, dan jumlah kasus malnutrisi juga jauh berkurang.

Hasil studi empiris tersebut menjelaskan bahwa memperbaiki iklim investasi membawa pengaruh yang lebih besar dari sekedar menciptakan pekerjaan dan memperbaiki taraf hidup. Perbaikan tersebut juga akan mendorong masyarakat untuk lebih banyak melakukan investasi pada pendidikan dan keterampilan mereka sendiri agar dapat memanfaatkan adanya pekerjaan yang lebih baik pada masa yang akan datang. Dengan demikian, peningkatan iklim investasi (infrasrtuktur) melengkapi upaya untuk meningkatkan sumber daya manusia. Mengingat dalam studi ini menghasilkan pengaruh investasi pemerintah terhadap kesejahteraan masyarakat adalah yang paling besar kontribusinya 
(55,80\%), maka cara yang paling cepat untuk meningkatkan kesejahteraan masyarakat adalah dengan memperbesar peran investasi pemerintah.

\section{Pengaruh Investasi Swasta Terhadap Pertumbuhan Ekonomi}

Hasil estimasi pengaruh langsung investasi swasta terhadap pertumbuhan ekonomi menunjukkan pengaruh positif dan signifikan dengan nilai koefisien jalur sebesar 0,401 dan nilai probabilitas sebesar 0,040. Pengaruh positif menunjukkan hubungan yang searah antara investasi swasta dengan pertumbuhan ekonomi. Artinya, peningkatan investasi swasta akan berdampak pada peningkatan pertumbuhan ekonomi di provinsi Maluku, demikian juga sebaliknya. Dengan demikian, berdasarkan pengujian hipotesis yang menyatakan bahwa investasi swasta berpengaruh signifikan terhadap pertumbuhan ekonomi kabupaten kota di provinsi Maluku adalah terbukti dan didukung oleh fakta.

Fakta adanya hubungan antara investasi dan pertumbuhan ekonomi dapat dilihat dalam struktur PDRB sisi pengeluaran (expenditure) kabupaten kota di provinsi Maluku. Pembentukan Modal Tetap Bruto (PMTB) terhadap PDRB di provinsi Maluku sejak tahun 2005 hingga tahun 2008 menyumbang 3,48\% sampai dengan 4,08 \% setiap tahun. Penyumbang PDRB terbesar di provinsi Maluku ternyata adalah dari Pengeluaran Konsumsi Rumah Tangga (PKRT) sebesar 71,64\% di tahun 2005 sampai dengan 72,68\% di tahun 2008. Hal ini memberi konsekwensi bahwa perekonomian provinsi Maluku sangat dipengaruhi oleh konsumsi rumah tangga.

Sektor konsumsi tidak dapat menciptakan nilai tambah bagi perekonomian sehingga tidak dapat mengatasi masalah pengangguran. Kondisi tersebut dengan sendidrinya akan berpengaruh terhadap pendapatan per kapita di provinsi Maluku yang sangat kecil jika dibandingkan dengan rerata daerah-daerah lain di Indonesia, perbedaannya cukup besar yakni sekitar tujuh juta rupiah. Rendahnya pendapatan per kapita tersebut, tentunya akan berimplikasi terhadap tingkat tabungan masyarakat yang juga ikut rendah. Tingkat tabungan yang rendah, maka akumulasi modal yang terkumpul untuk investasi tentunya akan rendah. Dengan adanya ketimpangan antara pendapatan yang kecil dan konsumsi yang tinggi di 
provinsi Maluku tersebut, maka kondisi tersebut harus dijembatani oleh investasi swasta baik dari dalam negeri maupun investasi asing.

Hal ini senada dengan yang dikemukakan oleh Jhingan (2004:137) bahwa, negara berkembang dapat berkembang dengan cara membatasi konsumsi dan meningkatkan tabungan. Di Indonesia, menurut Fathonah (2009), kebutuhan investasi sektor riil tidak dapat terpenuhi dari tabungan masyarakat. Oleh karena itu, dibutuhkan investasi asing untuk memenuhi kebutuhan investasi riil. Kebutuhan investasi dari luar negeri ini mutlak diperlukan mengingat keterbatasan sektor perbankan dan pasar modal di Indonesia yang belum berkembang maksimal. Khusus untuk provinsi Maluku, investasi swasta sangat diperlukan untuk pembangunan karena tabungan regional memang tidak besar.

Secara konseptual, teori pertumbuhan Sollow menyatakan bahwa disamping ketersediaan tabungan untuk investasi diperlukan pula peningkatan teknologi agat pertumbuhan dapat meningkat secara signifikan. Syarat yang harus dipenuhi agar terjadi peningkatan teknologi produksi di Indonesia menurut Wie (2006) dalam (Soekro.2008:90), di antaranya adalah melalui PMA. Pendapat tersebut didukung oleh Atje et al. (2005) yang menekankan bahwa salah satu cara paling efektif yang dapat ditempuh untuk meningkatkan teknologi produksi, adalah dengan mengundang PMA.

Apalagi, dengan diterapkannya otonomi daerah maka kompetisi dalam menarik FDI tidak hanya terjadi antar negara tetapi juga antar kabupaten dan kota baik dalam satu provinsi maupun lintas provinsi. Oleh karena itu, provinsi Maluku sangat berkepentingan untuk menarik lebih banyak lagi investasi domestik maupun investasi asing.

\section{Pengaruh Investasi Swasta Terhadap Kesejahteraan Masyarakat}

Hasil estimasi pengaruh langsung investasi swasta terhadap kesejahteraan masyarakat menunjukkan pengaruh positif dan signifikan dengan nilai koefisien jalur sebesar 0,075 dan nilai probablitas sebesar 0,004. Pengaruh positif menunjukkan hubungan yang searah antara investasi swasta dengan kesejahteraan masyarakat. Artinya, peningkatan investasi swasta akan berdampak pada peningkatan kesejahteraan masyarakat di provinsi Maluku, demikian juga sebaliknya. Dengan demikian, berdasarkan pengujian hipotesis yang menyatakan 
bahwa investasi swasta berpengaruh signifikan terhadap kesejahteraan masyarakat kabupaten kota di provinsi Maluku adalah terbukti dan didukung oleh fakta.

Hasil pengujian statistik ini didukung oleh fakta bahwa walaupun di tahun 2008 terdapat 45 perusahaan yang terdiri atas investor dalam negeri maupun investor asing, tenaga kerja Indonesia maupun asing yang terserap mencapai 13.855 orang. Kondisi ini sangat berbeda jika dibandingkan jumlah industri kecil yang terdiri atas industri pangan, industri sandang, industri kimia bahan bangunan, industri logam elektronik dan industri kerajinan yang menacapai 2.300 unit usaha. Banyaknya jumlah industri kecil tersebut, ternyata hanya dapat menyerap tenaga kerja sebesar 10.463 orang (BPS.2009(f) : 346-348).

Dengan besarnya jumlah tenaga kerja yang terserap melalui investasi swasta dalam negeri maupun investasi asing tersebut akan dapat meningkatkan Indeks Pembangunan Manusia (IPM) kabupaten/kota di provinsi Maluku. Hal ini disebabkan oleh karena peningkatan kesejahteraan masyarakat bila dilihat dari sisi ekonomi (aspek pendapatan), maka salah satu faktor penunjang utama adalah tersedianya lapangan pekerjaan sebagai sumber nafkah. Oleh karena itu, makin tinggi aktifitas ekonomi yang diawali dengan aktifitas investasi disuatu daerah, maka makin tinggi pula kesejahteraan masyarakat di daerah tersebut.

Fakta tersebut mendukung pendapat Arsyad (2005:109) bahwa, setiap upaya pembangunan ekonomi daerah mempunyai tujuan utama untuk meningkatkan jumlah dan jenis peluang kerja untuk masyarakat daerah. Pendapat tersebut juga mendukung pendapat Tambunan (2010:354) bahwa, keberhasilan desentralisasi akan sangat tergantung pada perkembangan dan pertumbuhan dunia usaha. Sektor swasta dengan mekanisme pasar adalah partner terbaik pemerintah dalam membangun ekonomi lokal dalam upaya meningkatkan output dan lapangan kerja.

Kecilnya pengaruh langsung investasi swasta terhadap pertumbuhan ekonomi menyebabkan pula kontribusi investasi swasta terhadap kesejahteraan masyarakat yang kecil $(0,56 \%)$. Terkait dengan hal tersebut, maka diperlukan pengembangan sektor swasta, menurut Tambunan (2010:50) peranan pemerintah yang paling tepat adalah: pertama, aktif mencari sumber pertumbuhan ekonomi baru dengan menciptakan lingkungan bisnis (iklim investasi) yang kondusif agar 
terjadi inisiatif enterprenuer untuk menghadapi dan melakukan investasi dalam ekonomi lokal. Peranan kedua yang strategis adalah menjaga keamanan dan pelaksanaan hukum yang terjamin. Dengan keamanan, kepastian hukum dan iklim usaha yang kondusif yang ditunjang dengan sarana dan prasarana yang memadai, maka diharapkan sektor swasta secara dinamis dapat melakukan perluasan kegiatan usaha.

\section{Pengaruh Pertumbuhan Ekonomi Terhadap Kesejahteraan Masyarakat}

Hasil estimasi pengaruh langsung pertumbuhan ekonomi terhadap kesejahteraan masyarakat menunjukkan pengaruh positif dan signifikan dengan nilai koefisien jalur sebesar 0,601 dan nilai probabilitas sebesar 0,000. Pengaruh positif menunjukkan hubungan yang searah antara pertumbuhan ekonomi dengan kesejahteraan masyarakat. Artinya, peningkatan pertumbuhan ekonomi akan berdampak pada peningkatan kesejahteraan masyarakat di provinsi Maluku, demikian juga sebaliknya. Dengan demikian, berdasarkan pengujian hipotesis yang menyatakan bahwa pertumbuhan ekonomi berpengaruh signifikan terhadap kesejahteraan masyarakat kabupaten kota di provinsi Maluku adalah terbukti dan didukung oleh fakta.

Tingkat pertumbuhan ekonomi yang mempengaruhi tingkat kesejahteraan masyarakat suatu daerah tergambar oleh kualitas dan kuantitas PDRB yang dihasilkannya. Secara kuantitas, tingkat pertumbuhan ekonomi provinsi Maluku telah mampu meningkatkan tingkat kesejahteraan masyarakat. Hal ini terlihat dari Indeks Pembangunan Manusia (IPM) sebagai indikator kesejahteraan di tiap kabupaten dan kota selama tahun 2006 sampai dengan tahun 2008 terus mengalami peningkatan.

Semakin besar dan berkualitas PDRB, maka semakin sejahtera masyarakatnya. Ini berarti bahwa sumber dan pola pertumbuhan itu dihasilkan adalah sangat penting untuk dicermati. Kualitas proses pertumbuhan yang tidak hanya melihat kecepatannya, terbukti mempengaruhi hasil pembangunan (Thomas et al. (2000:xxxi). Hal ini dapat diilustrasikan bahwa bukan hanya banyaknya makanan, melainkan kualitas dari makanan itu juga yang mempengaruhi kesehatan dan angka harapan hidup masyarakat. Itulah sebabnya mengapa eksplorasi terhadap struktur pertumbuhan merupakan hal yang sangat esensial. 
Perubahan struktur ekonomi dengan pertumbuhan ekonomi berbasis pada penyerapan tenaga kerja yang tinggi dengan capaian pengurangan kemiskinan dan penciptaan tenaga kerja adalah merupakan model pertumbuhan ekonomi regional yang lebih tepat diterapkan. Di provinsi Maluku, struktur pertumbuhan ekonomi tidak seimbang antara sektor tradable dan sektor non-tradable. Sektor tradable adalah sektor barang yang erat kaitannya dengan produksi dan perdagangan (Pertanian, Pertambangan, Penggalian, dan Manufaktur), sedangkan sektor nontradable adalah sektor jasa-jasa yang tidak dapat diperdagangakan secara internasional dengan leluasa (Listrik, Gas dan Air, Konstruksi, Perniagaan Umum, Hotel dan Restoran, Transportasi dan Komunikasi, Keuangan, serta Jasa-Jasa Umum) (Basri. 2009:47-48).

Setelah kontribusi sektor tradable dirata-ratakan, nilai kontribusi sektor tersebut dari tahun 2005 ke tahun 2008 terus mengalami penurunan. Secara berturut-turut persentase kontribusinya adalah $13,05 \%$ di tahun $2005,12,8 \%$ di tahun 2006, 12,62 \% di tahun 2007, dan 12,55\% di tahun 2008. Kondisi tersebut berbanding terbalik dengan sektor Non-Tradable yang dari tahun ke tahun terus mengalami peningkatan kontribusi. Di tahun 2005 hingga tahun 2008, peningkatan kontribusi secara berurutan adalah 10,14 \%, 10,27 \%, 10,36 \%, 10,40 $\%$. Kesenjangan pertumbuhan antara kedua sektor inilah yang dikatakan sebagai pertumbuhan ekonomi yang timpang atau tidak seimbang.

Pertumbuhan ekonomi yang terlalu bertumpu pada sektor non-tradable tersebut menurut Basri (2009:51) sangat beresiko, karena secara umum sektor jasa ini padat modal dan padat teknologi, terhimpun hanya pada pusat-pusat kemajuan/ekonomi yang biasanya berupa kota-kota besar serta sangat sedikit menyerap tenaga kerja. Hanya segilintir orang tertentu yang dapat berperan di sektor ini, yakni mereka yang punya akses besar pada sumber daya manusia dan modal. Sedangkan mayoritas penduduk selebihnya hanya akan menjadi konsumen.

Hal ini sangat kontras dengan sektor tradable atau sektor barang yang dapat menyerap begitu banyak tenaga kerja dan keuntungannya dapat dinikmati oleh banyak pihak. Dengan demikian, maka dapat dipastikan peningkatan sektor tradable lebih menguntungkan bagi provinsi Maluku yang penduduknya masih 
banyak menggangur serta masalah kemiskinan. Berdasarkan data kemiskinan (BPS. 2007(e):125 dan 2009(e):118), penduduk miskin yang bekerja di sektor pertanian terus mengalami peningkatan dan menampung tenaga kerja paling banyak di banding dengan sektor non-pertanian. Pada tahun 2005, penduduk miskin yang bekerja disektor pertanian di provinsi Maluku adalah sebesar 57,56 $\%$, kemudian persentase tersebut meningkat di tahun 2006 sebesar 65,56\% dan di tahun 2008 telah menjadi 80,05\%.

Besarnya penduduk miskin yang bekerja di sektor pertanian tersebut dapat disebabkan oleh karena proses transformasi perekonomian yang terjadi di provinsi Maluku itu tidak seimbang. Di mana, penurunan pangsa relatif sektor primer dalam perekonomian belum diiringi dengan atau diimbangi dengan penurunan persentase tenaga kerja di sektor primer. Data menunjukkan bahwa walaupun penyumbang PDRB terbesar adalah pada sektor tersier, namun tingkat penyerapan tenaga kerjanya pada tahun 2005, 2006 dan 2008 relatif kecil dibandingkan dengan sektor primer. Sektor industri (sektor tersier) yang diyakini sebagai sektor yang dapat memimpin sektor-sektor lain dalam perekonomian menuju kemajuan, kontribusinya bahkan yang paling sedikit. Padahal secara konseptual, pembangunan ekonomi dikatakan berhasil apabila peranan sektor industri manufaktur (sektor sekunder) semakin meningkat dari waktu ke waktu. Mengatasi pertumbuhan ekonomi yang tidak seimbang itu tentunya bukan dengan menekan atau menghalangi pertumbuhan sektor non-tradable melainkan dengan mengupayakan agar sektor tradable dapat tumbuh lebih baik dan cepat, agat tidak terlalu tertinggal dari sektor non-tradable. Pentingnya hal ini disebabkan oleh karena dengan pertumbuhan ekonomi yang timpang, akan menimbulkan masalah ketimpangan distribusi pendapatan dan keresahan sosial.

Selain itu, mengingat pembangunan daerah hanya akan berjalan dan berhasil dengan baik apabila kebijakan pembangunan yang diambil sesuai dengan kondisi daerah, yaitu berdasarkan masalah, kebutuhan dan potensi ekonomi daerah. Salah satu upaya yang dapat dilakukan untuk mengatasi tingkat pertumbuhan ekonomi yang tidak seimbang tersebut adalah melalui pengembangan industrialisasi berbasis pertanian/perikanan. Alasannya adalah: pertama, ketahanan pangan merupakan persayaratan agar pembangunan ekonomi 
khususnya industrialisasi dapat dilaksanakan. Tanpa ketahanan pangan yang mantap, maka kondisi sosial, ekonomi dan politik tidak akan stabil, sehingga pembangunan tidak akan dapat dilaksanakan. Kedua, sebagian besar penduduk provinsi Maluku tinggal di sepanjang garis pantai yang berada di pedesaan, sementara perekonomian di desa berbasis pada sektor pertanian/perikanan. Oleh karena itu, pembangunan di desa berbasis pada sektor pertanian/perikanan merupakan cara terbaik untuk memacu pertanian/perikanan desa. Ketiga, angkatan kerja penduduk sebagaian besar berada di wilayah pedesaan, di mana sebagian besar kesempatan kerja berasal dari sektor pertanian/perikanan. Keempat, selain bahan pangan akhir, sebagian besar praktek pertanian/perikanan adalah produk antara yang menjadi bahan baku industri sehingga terdapat keterkaitan produk sektor primer dan sekunder. Kelima, peningkatan pendapatan masyarakat pedesaan melalui industrialisasi pertanian/perikanan, selain menciptakan surplus lebih besar atau re-investasi di wilayah tersebut, juga mampu meningkatkan penerimaan daerah melalui pajak.

Hal ini didukung oleh Tambunan (2010:173,67), membangun industri bagi daerah otonom sebaiknya dimulai pada awalnya mengandalkan sumber daya alam dan tenaga kerja yang relatif masih berlimpah dan murah, kemudian baru melangkah pada ketahanan industri yang lebih maju. Menurutnya, industrialisasi harus dimulai dari pengembangan industri-industri yang ditekuni rakyat seperti agroindustri, pangan, kerajinan, dan industri pertanian pedesaan. Beragam jenis industripun (utamanya industri manufaktur) harus terus menerus dikembangkan, karena proses industrialisasi dibutuhkan untuk mentrasformasi masyarakat tradisional berbasis pedesaan kearah masyarakat industri maju dan modern. Pengembangan industri manufaktur akan mendidik masyarakat mengenai pentingnya kreatifitas, produktivitas, upah, menghargai waktu dan disiplin kerja, sehingga membuat individu semakin terikat dengan output ekonomi.

\section{Pengaruh Tidak Langsung Antar Variabel}

Berdasarkan hasil analisis menunjukkan bahwa investasi pemerintah cenderung berpengaruh secara langsung terhadap kesejahteraan masyarakat, sedangkan investasi swasta cenderung mempengaruhi kesejahteraan masyarakat 
melalui pertumbuhan ekonomi. Hal ini menandakan bahwa investasi pemerintah merupakan variabel yang sangat kuat mempengaruhi kesejahteraan masyarakat kabupaten kota di provinsi Maluku. Dengan demikian, maka variabel investasi pemerintah ini patut diprioritaskan dalam upaya meningkatkan meningkatkan kesejahteraan masyarakat.

\section{KESIMPULAN}

Beberapa kesimpulan yang diperoleh dari penelitian ini adalah sebagai berikut pertama, investasi pemerintah berpengaruh positif dan signifikan terhadap pertumbuhan ekonomi kabupaten kota di provinsi Maluku dengan kontribusi pengaruh sebesar 22,18\%. Arah hubungan yang positif menunjukkan bahwa peningkatan investasi pemerintah akan menyebabkan peningkatan kesejahteraan masyarakat. Kedua, investasi pemerintah berpengaruh positif dan signifikan terhadap kesejahteraan masyarakat kabupaten kota di provinsi Maluku dengan kontribusi pengaruh sebesar 55,80\%. Arah hubungan yang positif menunjukkan bahwa peningkatan investasi pemerintah akan menyebabkan peningkatan kesejahteraan masyarakat.

Ketiga, investasi swasta berpengaruh positif dan signifikan terhadap pertumbuhan ekonomi kabupaten kota di provinsi Maluku dengan kontribusi pengaruh sebesar $15,52 \%$. Arah hubungan yang positif menunjukkan bahwa peningkatan investasi swasta akan dapat menyebabkan peningkatan kesejahteraan masyarakat. Keempat, investasi swasta berpengaruh positif dan signifikan terhadap kesejahteraan masyarakat kabupaten kota di provinsi Maluku dengan kontribusi pengaruh sebesar 0,56 \%. Arah hubungan yang positif menunjukkan bahwa peningkatan investasi swasta akan dapat menyebabkan peningkatan kesejahteraan masyarakat.

Kelima, pertumbuhan ekonomi berpengaruh positif dan signifikan terhadap kesejahteraan masyarakat kabupaten kota di provinsi Maluku dengan kontribusi pengaruh sebesar $36,12 \%$. Arah hubungan yang positif menunjukkan bahwa peningkatan investasi swasta akan dapat menyebabkan peningkatan kesejahteraan masyarakat. Keenam, secara simultan dapat disimpulkan banwa secara langsung, investasi pemerintah dan investasi swasta berpengaruh positif dan signifikan terhadap pertumbuhan ekonomi serta kesejahteraan masyarakat baik secara 
langsung maupun tidak langsung. Kemudian, pengaruh secara langsung mempunyai kontribusi pengaruh yang lebih besar dibanding dengan pengaruh secara tidak langsung. Sedangkan, variabel yang paling besar pengaruh langsungnya terhadap kesejahteraan masyarakat adalah investasi pemerintah, sedangkan yang paling kecil pengaruhnya terhadap kesejahteraan adalah investasi swasta.

\section{Saran}

Pertama, melihat dampak investasi pemerintah yang besar terhadap pertumbuhan ekonomi maupun terhadap kesejahteraan masyarakat, maka pemerintah daerah diharapkan lebih meningkatkan porsi jumlah belanja modal/investasi pemerintah dalam bentuk infrastruktur atau prasarana dasar khususnya untuk sektor tradable. Kedua, pemerintah daerah kabupaten kota di provinsi Maluku tidak bisa lagi mengandalkan pertumbuhan ekonomi pada konsumsi. Salah satu faktor yang strategis adalah bagaimana memperkuat sektor swasta dan investasi dapat ditingkatkan ditiap daerah. Oleh sebab itu, disamping kondisi makro ekonomi yang stabil serta jaminan keamanan, diperlukan perbaikan iklim investasi yang kondusif yang mencakup perbaikan mekanisme peraturan perundangan, percepatan proses pendirian dan ijin usaha, perbaikan sistem informasi investasi secara on-line, serta melakukan promosi investasi melalui media cetak maupun elektronik. Apabila sektor swasta besar peranannya dan kegiatan ekonomi meluas, maka pertumbuhan ekonomi, penciptaan lapangan kerja akan meningkat.

Ketiga, investasi Pemerintah juga perlu lebih diarahkan untuk peningkatan investasi modal manusia (human capital) melalui peningkatan kualitas kesehatan dan pendidikan sebagai alat kebijakan penting dalam strategi pemerintah daerah untuk meningkatkan pertumbuhan ekonomi dan kesejahteraan masyarakat.

Keempat, guna pengembangan keilmuan lebih lanjut, diperlukan studi empirik yang lebih mendalam yang terkait dengan tema studi ini. Oleh sebab itu untuk penelitian yang berikutnya, diharapkan dapat memperluas cakupan periode penelitian dan memperluas cakupan variabel seperti variabel investasi swasta dan kesejahteraan masyarakat. 


\section{DAFTAR PUSTAKA}

Arsyad Lincolin. 2005. Pengantar Perencanaan Pembangunan Ekonomi Daerah, Edisi Kedua. Yogyakarta. BPFE.

Atje, Aswicahyono, Haryo, Raimond dan Thee Kian Wie. 2005. Indonesia's Industrial Competitiveness: A Study of the Garment, Auto Parts and Electronic Component Industries. Report Submitted to the Development Economics Research Group. The World Bank.

Badan Pusat Statistik. 2006,2007,2008,2009. Maluku Dalam Angka. Ambon.

2007,2008. Indeks Pembangunan Manusia Tahun 2005 2006 dan 2006 - 2007. Jakarta.

2007,2008. Statistik Keuangan Pemerintah Daerah Kabupaten/Kota Tahun 2005 - 2006 dan 2006 - 2007 Jakarta.

2009. Produk Domestik Regional Bruto Propinsi-Propinsi Di Indonesia Menurut Penggunaan Tahun 2004 - 2008. Jakarta.

Badan Perencanaan dan Pembangunan Nasional (BAPPENAS) dan United Nations Development Programme (UNDP). 2008. Studi Evaluasi Dampak Pemekaran Daerah. Bridge (Building and Reinventing Decentralised Governance). Jakarta.

Basri Faisal. 2009. Catatan Satu Dekade Krisis; Transformasi, Masalah Struktural, dan Harapan Ekonomi indonesia. Jakarta. Esensi, Erlangga Group.

Cui, Qiang, Emanuele Baldacci, B. C., Sanjeev Gupta. 2008. Social Spending, Human Capital, and Growth in Developing Countries. World Development Vol.36 No.8.

Jhingan, M.L, 2004. Ekonomi Pembangunan dan Perencanaan. Jakarta: PT. Raja Grafindo Persada.

Loizides John dan George Vamvokas. 2005. Government Expenditure And Economic Growth: Evidence From Trivariate Causality Testing. Jounal Of Applied Economics. Vol.8,Iss.1, May:125-128.

Muhidin S.A, Maman Abdurahman.2007. Analisis Korelasi, Regresi, dan Jalur Dalam Penelitian (Dilengkapi Aplikasi Program SPSS). Bandung. Pustaka Setia.

Prawirosetoto Yuwono. FX. 2004. Desentralisasi Fiskal di Indonesia. Jurnal Ekonomi dan Bisnis. Jakarta. Vol.XI. pp.15-29.

Soekro R.I, A. Herlianto, M.T Amrozy, Susilorini, A. Lestari Y.S, G. Padoli, Binhadi, A. Firmansyah, dan A.A Rasyid. 2008. Bangkitnya Perekonomian Asia Timur, Satu Dekade Setelah Krisis. Jakarta: PT. Elex Media Komputindo.

Tambunan Mangara. 2010. Menggagas Perubahan Pendekatan Pembangunan; Menggerakkan Kekuatan Lokal dalam Globalisasi Ekonomi. Yogyakarta. Graha Ilmu. 
Tim Peneliti Centre for Political Studies Soegeng Sarjadi Syndicated. 2001. Potensi Masa Depan Republik Indonesia. Jakarta: Gramedia Pustaka Utama.

The World Bank. 2004. World Development Report: A Better Investment Climate for Everyone. Washington, DC. Oxford University Press.

Thomas Vinod, Mansoor Dailami, Ashok Dhareshwar, Daniel Kaufmann, Nalin Kishor, Ramon Lopez, Yan Wang. 2000. The Quality of Growth. Washington D.C: The International Bank for Reconstruction and Development/The World Bank.

UNDP, BPS dan BAPPENAS. 2001. Indonesia Human Development Report 2001. The Economics of Democracy: Financing Human Development in Indonesia. Published Jointly By BPS - Statistics Indonesia, Bappenas and UNDP Indonesia.

Widodo Suseno Triyanto. 1990. Indikator Ekonomi, Dasar Perhitungan Perekonomian Indonesia. Yogyakarta: Kanisius.

Zagler, Martin, and G. Durnecker. (2003). Fiscal policy and Economic Growth. Journal of Economic Surveys. Vol.17 No.3. pp. 53-74. 